\title{
The Russian Military in 2020: Russia's Way Back to Power Projection? Implications for NATO
}

\author{
Thomas Braun*
}

\section{Introduction}

"Russia Has Lost its Army." This headline of an editorial published on the global defense and military portal DefenceTalk in October 2003 gives proof of the perception of the Russian military leadership at the beginning of the twenty-first century. ${ }^{1}$ The developments after the collapse of the Soviet Union led to multiple efforts to reform the Russian armed forces. In the early 1990s, former Russian Defense Minister Pavel Grachev initiated a number of military reforms, but met heavy resistance within the Russian officer corps (still strongly influenced by the Soviet era) who were trying to preserve their system and positions. ${ }^{2}$ Most of the additional reform efforts of the last twenty years - which were mostly limited to downsizing manpower and equipment, without addressing the larger military system and organizational structure-failed to achieve the goal of a restructured modern Russian military. This led the Russian military journalist Alexander Goltz to publish a book in 2004 titled The Army of Russia: 11 Lost Years, in which he concludes that between 1993 and 2004 the military reforms that were carried out in Russia had no meaningful results. ${ }^{3}$ In response to the lack of progress in armed forces reform, the newly appointed civilian Defense Minister Anatoly Serdyukov introduced the so-called "New Look" on 23 February 2008. Will the "New Look" reforms lead to the "reappearance of the Red Star," the symbol of the former Soviet Army? What are the possible implications of such a resurgence for NATO? To understand the imperatives behind Serdyukov's "New Look," it is necessary to understand Russia's national interests, as every government will calculate their military reforms based on their perceived national interests, as well as on identified threats and risks.

Major (GS) Thomas Braun, Dipl.-Päd.(univ.), is an Air Force Officer with operational deployments to the Balkans and Sudan. He is an Alumni of the George C. Marshall Center and graduated the German General Command and Staff College. Currently Thomas Braun is serving on the Staff of the German Military Representative in the NATO Military Committee at NATO HQ in Brussels. As a member of the Military Preparatory Committee (MPC) of the NATO-Russia Council Military Representatives he is enrolled in the further development of NATO-Russia relations. Additionally he is focusing on NATO Capability Development and all pillars of NATO Common Resources. The views expressed in this article are strictly the personal opinion of the author.

1 "Russia Has Lost its Army," DefenceTalk (21 October 2003); available at http://www.defencetalk.com/russia-has-lost-itsarmy-1384.

2 Timothy L. Thomas, Recasting the Red Star: Russia Forges Tradition and Technology through Toughness (Fort Leavenworth, KS: Foreign Military Studies Office, 2011), 11.

3 Ibid. 


\section{Key Aspects of Russian Foreign Policy}

Since the collapse of the Soviet Union, Russia's national interests have remained basically unchanged, with one exception. The importance of economic prosperity with respect to oil, natural gas, and other extractive resources has risen considerably, as this wealth is perceived as the foundation of any Russian attempt to tackle existing and future domestic challenges, as well as a way back to gaining dominance in Russia's socalled "near abroad." ${ }^{4}$ Russia's traditional national interests, which are stated in the July 2008 Foreign Policy Concept and the 2009 National Security Strategy, include bolstering demographic health and security as well as maintaining security on its borders and within the near abroad. Additionally, Russia wants to ensure that it remains the primary actor in the region, especially in Central Asia. ${ }^{5}$ The more recently published "New Military Doctrine" of February 2010 refers to the importance of the "near abroad" and underlines Russian concerns about NATO encroachment in this region. To ensure its regional dominance and to protect Russian interests, the Russian armed forces "might be used operationally outside Russia" unilaterally, according to this doctrine. ${ }^{6}$ Russia seems also to be more willing to deploy their forces within the arrangements of the Collective Security Treaty Organization. ${ }^{7}$ Russia's national interests and their translation into the New Military Doctrine as well as the ongoing focus on the "near abroad" have to be considered when analyzing any efforts to reform Russia's military.

\section{After the "Collapse of the Red Army": Russian Forces at the Beginning of the Twenty-first Century}

"Not since 1941 has the Russian military stood as perilously close to ruin as it does now," stated Dr. Alexei Arbatov, the Deputy Chairman of the Defense Committee in the Duma in $1998 .{ }^{8}$ At the beginning of the twenty-first century, the Russian armed forceswhich inherited the larger part of the Soviet Red Army in terms of soldiers and equipment - still struggled with a heritage that relied heavily on the mentality of the Soviet era and with the legacy of outdated equipment. The first review of Russia's military doctrine, carried out in 1993, was largely unsuccessful in organizing the Russian forces and in changing the old Soviet military mentality; Russian forces were spread out all over the expansive area of the former Soviet Union, with a lack of general strategy and

4 The "near abroad" includes Belarus, Ukraine, Georgia, Azerbaijan, Turkmenistan, Uzbekistan, Kyrgyzstan, and Tajikistan. See David Capezza, "Translating Russia's Military Reform," in Small Wars Journal (2009): 3; available at http://smallwarsjournal.com/jrnl/art/translatingrussias-military-reform.

5 Ibid.

6 Marcel de Haas, "Russia's Military Doctrine Development," in Russian Military Politics and Russia's 2010 Defense Doctrine, ed. Steven Blank (Carlisle, PA: Strategic Studies Institute, U.S. Army War College, 2010), 42.

7 Ibid., 45.

8 Alexei G. Arbatov, "Military Reform in Russia: Dilemmas, Obstacles, and Prospects," International Security 22:4 (Spring 1998): 83. 
organization. ${ }^{9}$ Although the lost campaign in Chechnya during the first Chechen War 1994-96 (as well as the disastrous storming of Grozny in 2004) helped highlight the lack of training and preparation in the Russian Army, which led to multiple efforts to introduce reforms, but none were successful. The Russian government succeeded in reducing the size of the armed forces, but the overall structure of the Russian military remained top-heavy, insufficiently trained, and poorly motivated. Under the guiding objectives of limiting expenditures while retaining sufficient forces to deter aggressors, Russia reduced the size of its armed forces from nearly 3 million soldiers in 1991 to 1.1 million in 2008, although the latest round of major reductions took place in 1999. ${ }^{10}$ Since then, calls for further reductions have been ignored. Moreover, the internal workings of the Russian armed forces were massively affected by corruption, and a system known as dedovshchina, an informal system of suppression of junior conscripts by senior enlisted soldiers (essentially, formalized hazing) that is still in place today. ${ }^{11}$ Growing corruption led Prime Minster Putin in 2003 to address the issue of corruption as one of the main priorities to focus on in the Russian armed forces. ${ }^{12}$ The problems that were mentioned were characteristic of the internal state of the military apparatus, although in 2012 a public webpage for official complaints within the Russian Military was introduced. In addition to these internal challenges, Russian equipment was completely outdated, and training became more difficult. Although Putin ordered that strategic bomber patrols be resumed, more than half of all air assets in the Russian Air Force were not combat ready and not maintained. In 2000, the average annual training time for Russian pilots was twelve hours, which was increased to forty hours in 2007, but is still an absolute minimal level to ensure combat readiness. ${ }^{13}$ The Russian Navy was facing similar challenges, as they ceased nearly all maritime operations except for coastal patrols in 2008 in order to save fuel. The Russian-Georgian War in August 2008 highlighted numerous problems concerning personnel, equipment, organizational structure, and even training regulations that dated back as far as $1980 .{ }^{14}$ Despite the Russian victory in its war with Georgia, the campaign was viewed as a disaster for a Russian military that lacked unified command, sufficient situational awareness, and even suffered heavy friendly-fire losses in the air force. ${ }^{15}$ A Russian officer characterized the Russian-Geor-

10

11

Dedovshchina is literally translated as the "grandfather rule." Kris D. Beasly, "Russian Military Reform from Perestroika to Putin: Implications for U.S. Policy," research paper prepared at Air University, Maxwell AFB, Alabama (April 2004), 79; available at www.dtic.mil/cgibin/GetTRDoc?AD=ADA427322.

12

13 Capezza, "Translating Russia's Military Reform," 11.

14 Dale R. Herspring, "Is Military Reform in Russia for 'Real'? Yes, but...," in The Russian Military Today and Tomorrow: Essays in Memory of Mary Fitzgerald, ed. Steven Blank and Richard Weitz (Carlisle, PA: Strategic Studies Institute, U.S. Army War College, July 2010), 153.

15 Ibid., 152-54. 
gian War thus: "It turns out that a twenty-first century [Russian] army did not go to battle - it was a Soviet army with models from the 1960s and 1980s in the past century." 16

\section{"The New Look": Russian Military Reforms of 2008}

The lack of a new military doctrine in 2008 in the wake of the Russian-Georgian War, the lack of a public debate on national security issues, and the scope of responsibilities of the Russian military led to discussions about whether or not true defense reform was necessary. The Vice President of the Association of Russian Diplomats, Andrei Baklanov, made his doubts about the need for reform clear when he said in 2009, "I see no major grounds for carrying out these reforms." 17 In case his feelings were misunderstood, he added, "Most reasons for the unsatisfactory condition of the armed forces ... have nothing to do with the lack of reform." 18 The editor of the magazine Russian Politics and Law, Dimitri Gorenburg, recognized the significance of the prospect of the first genuine occurrence of defense sector reform since the breakup of the Soviet Union, and acknowledged the seriousness of such a project. In February 2007, President Vladimir Putin appointed the civilian Anatoly Serdyukov as Russia's new Minster of Defense. This marked the first time that a civilian would serve as Minister of Defense in the Russian Federation since the collapse of the Soviet Union. Serdyukov was from St. Petersburg, like Putin, and had the backing of both Prime Minister Medvedev and President Putin, who charged Serdyukov with the objectives of fighting corruption and inefficiency in the armed forces. ${ }^{19}$ Without any prior notice he introduced a set of transformations called the "New Look"- - studiously avoiding the biased term "reform"- in October of 2008, although the term "the Military Reform of 2008" is widely used. The Russian-Georgian War in the summer of 2008 certainly acted as catalyst for the introduction of the "New Look," which is regarded as the most radical systemic change in the Russian military since "the reforms initiated by Dmitry Milyutin in the second half of the nineteenth century." 20

A wide range of changes were announced in Serdyukov's "New Look" plan, which included four key dimensions of transformation: ${ }^{21}$

1. Restructuring the officer corps. With an officer/enlisted ratio of 3:1 in the Russian military, it was necessary to reduce the number of officers from 355,000 to $150,000 .{ }^{22}$ Most of the surplus officers were serving in so-called "skeleton

16 Ibid., 155.

17 Nezavisimoe voennoe obozreni (translated transcript of round table), "Urgent Problems and the Logic of Military Reform," Russian Politics and Law 48:3 (May-June 2010): 59.

18 Ibid., 59.

19 Thomas, Recasting the Red Star, 11-12.

20 Ilya Kramnik, "Military Reform: Basic Guidelines," RIA Novosti (24 February 2010); available at http://en.rian.ru/analysis/20100224/157995299.html.

21 Pavel K. Baev, "Military Reform Against Heavy Odds," in Russia After the Global Economic Crisis, ed. Anders Aslund, Sergei Guriev, and Andrew Kuchins (Washington, D.C.: Peterson Institute for Internal Economics, May 2010), 170-72.

22 Herspring, "Is Military Reform in Russia for 'Real'?," 160. 
units," which were non-operational, and would only be manned in case of mobilization. While reducing the number of officers at all ranks save young lieutenants, the reform also proposed establishing a non-commissioned officer corps that did not exist at the time in the Russian armed forces. With the creation of a new non-commissioned officer (NCO) corps, the system of dedovshchina could be countered, and the level of professionalism in the military would rise, as experience at the squad and platoon levels would be retained in the Russian military longer than in the past.

2. Reorganizing the command and control structure. The Russian-Georgian War showed the lack of flexibility and unity of command in the Russian armed forces. Therefore, the "New Look" reforms included the reorganization of a four-level command structure (military district-army-division-regiment) to a more flexible and sustainable three-level model (military district-operational command-brigade), where district commanders now have command of all formations in their area of responsibility except for Strategic Missile Forces. As an independent tactical formation, the brigade offers more flexibility and requires less external support in operations. ${ }^{23}$

3. Elimination of "skeleton units." The abolishing of reduced-strength cadre units - the so-called "skeleton units"-implies the end of mass mobilization. Although some aspects of the mobilization plans will be preserved, such as weapons storage facilities and equipment, the numbers of units will be reduced from 1890 units to only 172 , all of which will then be fully manned with professional soldiers, and known as "permanent readiness units." ${ }^{24}$ Of the 22,000 tanks previously deployed with Russian land forces, only 2,000 tanks will remain for operations according to Serdyukov's "New Look."

4. Reshaping the system of military education. The decrease in military personnel and a high level of duplication within the Russian armed forces led to the decision to combine Russia's military educational institutions. Serdyukov decided to reduce the number of military educational centers from sixty-five institutions of various kinds to only ten: three joint centers, six academies, and one military university by $2013 .{ }^{25}$

In addition to these four key directions, Serdyukov also decided that the overall strength of the Russian forces would be cut to one million soldiers by 2013, instead of by the initially projected target date of $2016 .{ }^{26}$ Parallel with the "New Look," a program of modernization of military equipment has been emphasized, as no new weapon systems have been introduced in the Russian armed forces in the fifteen years since the be-

23 Ibid., 165.

24 Baev, "Military Reform Against Heavy Odds," 170.

25 Herspring, "Is Military Reform in Russia for 'Real'?," 161.

26 Steven Blank, ed., Russian Military Politics and Russia's 2010 Defense Doctrine (Carlisle, PA: Strategic Studies Institute, U.S. Army War College, 2010), 166. 
ginning of the reform process. ${ }^{27}$ In 2008 , only 10 percent of the Russian military's armaments was considered "modern"; the goal is to increase this share to 30 percent by $2015 .{ }^{28}$ For this reason, the State Armaments Program (SAP) promised USD 704.9 Billion from 2011 to 2020 in order to modernize the equipment available to the Russian forces. ${ }^{29} \mathrm{~A}$ large portion of these funds will be used for the modernization of the nation's nuclear weapons capability, which is regarded as a guarantee for safeguarding Russia, followed by investments in space weapons and air defense. Additional emphasis will be devoted to the fields of communications, command and control, and strategic mobility.

\section{Challenges and Achievements of the Military Reform in 2011}

The reaction among the senior ranking officers to Serdyukov's "New Look" set of reforms was resolutely negative. As one researcher stated, "all officers at the three- or four-star level in key bureaucratic positions either submitted their retirement papers or were fired." ${ }^{30}$ The resistance to the radical changes initiated by Minister Serdyukov was quite strong, but despite the opposition from senior military leaders and within the administration, all projects made sufficient progress so that a "point of no return" had been reached by 2010. Diverging comments have been made in public concerning the status and achievements of these reforms. In particular, senior military leaders and the top political leadership seem to have different understandings of progress. The latest appointments of the Chiefs of Services (Army, Air Force and Navy) were clearly a sign pro reform as all new Chiefs supported Serdyukovs line of communication. In October 2011 Defense Minister Serdyukov signaled that the first stage of the reforms - which primarily concerned the organizational changes and the decommissioning of the cadre unitswas "nearing completion." He continued to announce the shift from reorganization to rearmament. ${ }^{31}$ But his assessment is not in line with the various challenges concerning the effort in the key reform fields mentioned above:

1. Restructuring the officer corps and creating an NCO corps. The "New Look" is facing enormous problems, as the recruitment of cadets to military schools has been suspended for two years. ${ }^{32}$ But it is not only the recruitment of cadets

27 Ilya Kramnik, "Russian Military Reform in Times of Crisis," RIA Novosti (15 March 2010); available at http://www.defencetalk.com/russian-military-reform-in-times-of-crisis-24920.

28 Pavel K. Baev, "Russian Military Perestroika," in U.S. Europe Analysis, no. 45 (Brookings Institution Center on the United States and Europe, 29 April 2010), 3.

29 Forecast International, "Three Key Factors at Play for Russian Modernization," DefenceTalk (14 April 2011); available at http://www.defencetalk.com/three-key-factors-at-play-forrussian-modernization-33469.

30 Herspring, "Is Military Reform in Russia for 'Real'?," 168.

31 Roger McDermott, "Serdyukov Signals 'First Stage' in 'Military Reform' Nearing Completion," Eurasia Daily Monitor 8:191 (18 October 2011); available at www.jamestown.org/ single/?no_cache $=1 \& t x \_t$ tnews $\% 5 \mathrm{Btt} \_n e w s \% 5 \mathrm{D}=38541 \& \mathrm{tx} \_\mathrm{ttnews} \% 5 \mathrm{BbackPid} \% 5 \mathrm{D}=512$.

32 Roger McDermott, "Russian Military 'New Look' Hovers in Limbo," Eurasia Daily Monitor 8:206 (8 November 2011); available at http://www.jamestown.org/single/?no_cache=1\&tx_ ttnews\%5Btt_news\%5D=38639\&tx_ttnews\%5BbackPid\%5D=512. 
that is at stake. Igor Barinov, Deputy Chairman of the Duma Defense Committee, confirmed that the new combat brigades were manned in 2011 at only 75 percent. He states that the shortfall is due to the lack of attractiveness of the Russian armed forces as a career, which he holds responsible for the failure to recruit enough soldiers on contract terms. ${ }^{33}$ Part of this lack of appeal of a military career is a result of not being able to completely get rid of the dedovshchina system, ${ }^{34}$ and the failure to create a professional NCO corps, which showed considerably in the VOSTOK 2010 exercises, where a shortage of trained sergeants was evident. ${ }^{35}$ The program is being delayed, as the estimated number of contracted NCO candidates could not be met due to many candidates' low education and poor health. The target for the NCO corps is 250,000 candidates, and it seems to be facing serious problems in attracting enough qualified and interested applicants. ${ }^{36}$ Another challenge rises from the mass dismissals of officers who were professionals available for quick deployments. This development led to an accelerated decline in combat readiness, and a lack of motivation that is sufficiently severe so that Major-General (ret.) Pavel Zolotarev, Deputy Director of the Institute of the United States and Canada at the Russian Academy of Sciences, stated that the Russian military is genuinely unprepared for large-scale combat at the moment. ${ }^{37}$ Finally, it presents a challenge to the military mentality, which is based on tradition and is perceived as being destroyed by the "New Look," to the point that "the Russian officer corps is in a state of chaos." 38

2. Reorganizing the command and control structure. One of the main shortcomings the Russian military experienced during the 2008 Russian-Georgian War was the lack of efficient command and control. The "New Look" led to a unification of command and control systems, since the different branches scrapped their individual systems in favor of a time-saving and efficient system of conformity of command and control, allowing for more streamlined decision making. ${ }^{39}$ In addition to the new three-level brigade-focused structure, an automated command and control system has been introduced, although it is not yet fully operational. This part of the reform has been successful, as Serdyukov reported

33 Ibid.

34 The Russian Ministry of Defense reported 1,700 incidents of hazing from January to September 2010. While this record is abysmal, it at least reflects that the Russian MoD is finally focused on the problem. In 2003, when asked about such issues as denial of food to younger soldiers and poor nutrition, Deputy Minister of Defense V. Isakov flatly denied the existence of such problems.

35 Thomas, Recasting the Red Star, 20.

36 Herspring, "Is Military Reform in Russia for 'Real'?," 171.

37 Nezavisimoe voennoe obozreni, "Urgent Problems and the Logic of Military Reform," 90.

38 Herspring, "Is Military Reform in Russia for 'Real'?," 168, 173.

39 Thomas, Recasting the Red Star, 14. 
on 1 December 2009 that eighty-five combat brigades could deploy out of the newly organized four military districts. ${ }^{40}$

3. Elimination of "skeleton units." The number of units in the Russian Army has been reduced by nearly 90 percent, in the Air Force by 48 percent, in the Navy by 49 percent, and in the Strategic Missile Forces by 33 percent. ${ }^{41}$ With the reduction in the size of the standing military, a modernization program is in place in order to achieve at least a 70 percent rate of modern equipment by 2020, although the existing constraints concerning the budgetary situation, especially consequences of a declining oil price, will have to be considered in the future. These radical cuts in the number of units were completed by 2010, and marked an end to the Soviet-era plans for mass mobilization. ${ }^{42}$

4. Reshaping the system of military education. The reshaped educational landscape of the Russian military will have considerably fewer joint academies and schools, but by 2013 will feature better coordination between institutions as well as an optimized curriculum. The general staff academy lost eighteen faculty positions, and admitted only sixteen officers in 2009, down from one hundred in 2008. It also changed the focus of its curriculum to involve more practical training, and also began requiring officers to learn a foreign language. ${ }^{43}$ The system of military education will need further focus, as the complex nature of modern crisis situations will demand an even broader educational background of officers.

Given the above-mentioned achievements, the level of combat readiness was expected to increase, due to the anticipated professionalism of the contracted soldiers who (it is hoped) will now remain in the military longer, as well as to the changes in personnel and organizational structure. By mid-2011 there were 180,000 contracted soldiers in the Russian military, a number that is supposed to rise to 425,000 by $2017 .{ }^{44}$ To enhance recruitment, a pay raise became effective on 1 January 2012 in order to make the forces more attractive. A result is still to be seen. In addition, the level of basic social and living conditions for soldiers in the Russian military will be improved. But Russia is facing additional non-military challenges concerning future demographic developments and health problems. The demographic imbalance in Russia, which has a rapidly aging

40 Ibid., 14-15.

Blank, Russian Military Politics and Russia's 2010 Defense Doctrine, 171.

42 Pavel Felgenhauer, "Rearmament Declared the Main Issue in Russian Military Reform," Eurasia Daily Monitor 7:122 (24 June 2010); available at www.jamestown.org/single/?no_cache= 1\&tx_ttnews\%5Btt_news\%5D=36521.

43 Thomas, Recasting the Red Star, 16.

44 "Senior Russian Army Officers Resign over Military Reforms - Paper," RIA Novosti (5 July 2011); available at http://en.rian.ru/mlitary_news/20110705/165026894.html. 
population, will lead to an insufficiently large pool of potential recruits. ${ }^{45}$ In 2011 , only 135,850 enlisted men were recruited, instead of the necessary 250-300,000 recruits, which led the Chief of the Russian General Staff, General Nikolai Makarov, to declare: "We have no one anymore who we can recruit." ${ }^{46}$ This will definitely impact the size of the forces, and will probably initiate a redesign of the military's overall size, with a limit of 600,000 to 700,000 soldiers. Concerning the level and quality of armaments available to the Russian military, the military-industrial complex in Russia is unable to cope with the needs of the Russian forces, which leads Russia to buy foreign military equipment such as night vision goggles or the Mistral Helicopter Landing Ships from France, or possible additional armor for combat vehicles from Germany. ${ }^{47}$ Another fact that bears on the field of armaments is Russia's fast-growing cooperation with India, which is becoming a special relationship with a strategic partner. ${ }^{48}$

As the Russian military-industrial complex needs more time to transition, there will be and must be more foreign military sales to modernize the Russian armed forces. More progress has been made than was initially anticipated, but the challenges facing the effort of military reform in Russia are numerous, and the risk of fragmentation facing the reforms is obvious. Russia's level combat readiness has declined since the "New Look" reforms were initiated. While this decline may have originated in the transitional phase of the reforms, and thus cannot be laid at the doorstep of the "New Look" program, it is certain that it will not be resolved anytime soon.

\section{Implications for NATO}

The New Military Doctrine of 2010 gives evidence that the Russian strategic community (or at least the authors of the doctrine) is not willing to give up the idea of a large-scale conflict with NATO. But when they confront reality, it becomes starkly apparent that by abolishing the "skeleton units," the mechanism for the mass mobilization of the Russian military will be lost, which implies abandoning the idea of waging a long-lasting conventional war. ${ }^{49}$ Indirectly it means that the idea of a conventional confrontation with NATO is no longer a probable option. And all efforts and achievements - as well as the challenges - in the area of defense reform thus far underline the fact that Russia is also relinquishing the possibility of a mobilization of the scope that would be needed to counter an attack launched by NATO. The current Russian armed forces pose no direct threat to NATO, but they still have a large stockpile of sub-strategic nuclear weapons that have to be considered. The planned expeditionary character of the new Russian

45 According to RIA Novosti, only 11.7 percent of young men aged 18-27 were eligible for the army. See "Russian Military Has 'No one left to draft'," RIA Novosti (17 November 2011);

46 Ibid.

47

48

Felgenhauer, "Rearmament Declared the Main Issue in Russian Military Reform."

"Medwedew lobt Beziehungen mit Indien als privilegierte Partnerschaft" [Medvedev Praises Relationship with India as a Privileged Partnership], RIA Novosti (16 December 2011); available at http://de.rian.ru/politics/20111216/262019506.html.

Baev, "Russian Military Perestroika," 2. 
military opens possibilities for joint missions, like peacekeeping or continued anti-piracy operations. In the remits of the NATO-Russia Concil (NRC), which was established in 2002, for example, these aspects are found within the key areas of cooperation between NATO and Russia. The Military-to-Military cooperation is focusing on preparation for possible future joint military operations. Initial participation of Russian naval assets in NATO operation Active Endeavour in 2006/2007 showed already the beneficial cooperation with Russia. Taking into consideration Russian foreign policy's focus on the "near abroad," it will continue to be essential to respect Russia as valuable partner for securing Central Asia, especially considering the rapid-deployment combat brigades that Russia will soon be able to put into the field. The reforms initiated by Defense Minister Serdyukov open the opportunity to strengthen defense relations between NATO and Russia, as Russia might be seeking additional advice on carrying out its reforms, although in the past year a more polemic tone has returned to the NATO-Russian dialogue, which might have been a product of the run-up to Russia's last presidential election in May 2012. ${ }^{50}$ But military reform is a concept that applies more broadly than to just the armed forces, so NATO may have the chance to offer their experience concerning procurement processes which partly takes place in the NRC and could be a stronger part of the annual Work Plan that structures the NATO-Russia cooperation. As First Deputy Defense Minister Popovkin admitted in 2008, "Modern military equipment is so complex, we will need foreign know-how, while continuing our own military research." ${ }^{51}$ Clearly, this statement could be taken to widen the potential fields of cooperation after the completion of the 2007 "Study on NATO-Russia Defence Industrial and Research and Technological Cooperation." 52 This is also an opportunity to upgrade the level of interoperability through programs of bilateral military cooperation, such as those the British agreed to in July $2012,{ }^{53}$ or by joint exercises like "Vigilant Skies 2011," where NATO and Russian fighters trained in intercepting hijacked airliners within the NRC-Comprehensive Airspace Initiative. To profit from Russia's desire to modernize its arsenal, NATO should welcome Russian procurement of Western technology and act as a multiplier by offering assistance, while at the same time remembering not to neglect concerns related to technology transfer. Finally, the pressing topic of missile defense could be an area of greater cooperation on possible joint systems, which would ensure the implementation of the U.S./NATO-dominated approach while enabling Russia to modernize her defense systems, as a nuclear conflict between Russia and NATO seems unlikely.

50 "Medvedev's Missile Shield Remarks May Be Election Rhetoric - NATO Chief," RIA Novosti (8 December 2011); available at http://en.rian.ru/world/20111208/169468939.html.

51 Felgenhauer, "Rearmament Declared the Main Issue in Russian Military Reform," 3.

52 “Nato's relations with Russia" (June 2012); available at http://www.nato.int/cps/en/natolive/ topics_50090.htm.

53 "Russia, Britain plan to improve military ties," RIA Novosti (19 July 2011); available at http://en.rian.ru/mlitary_news/20110719/165282948.html, http://www.defencetalk.com/russia britain-plan-to-improve-military-ties-35777 (5 December 2011). 
On 7 December 2011, in the final statement at the North Atlantic Council (NAC) meeting in Brussels, the NATO Foreign Ministers "reaffirmed that NATO-Russia cooperation remains of strategic importance. ... We are also engaged in improving trust and transparency in defense transformation, strategy, doctrines, military posture, and military exercises. We want to see a true strategic partnership between NATO and Russia, and we will act accordingly, with the expectation of reciprocity from Russia." ${ }^{54}$ This clearly indicates that NATO is willing to use the NRC as the appropriate vehicle for NATORussia cooperation and offers assistance via cooperation and trust building that might be well used if the Russian Defense Ministry overcomes its antiquated attitudes towards NATO and would accept support in advancing the "New Look" military reforms. From the Russian perspective, it would be important that any assistance offered be presented as an option, and not as indoctrination. If interoperability is reaching the level of NATO standards, and if political obstacles can be left behind, NATO might be well served to rethink their position and evaluate the option for Russia becoming more than a special affiliate, with possible future contributions to NATO operations.

\section{The Russian Military in 2020: Re-Rising of the "Red Star," or a "New NATO Member"?}

"Russia today lacks a clear hierarchy for strategic decision making and control," declared a participant in a 2010 round table discussion on military reform in Russia. ${ }^{55}$ However, Defense Minister Serdyukov has taken some of the steps demanded by the new complex global security environment. During the run-up to the Russian presidential elections in 2012, the tone of the debates became harsher, and the contradictions between the New Russian Military Doctrine, signed by President Medvedev, and the process of Russian military reform became more obvious. The current achievements and outcomes of the "New Look" reforms predict a more flexible and expeditionary military - a force that has less to do with the goals of the Russian Military Doctrine than with the material and demographic realities of life in today's Russia. In order to understand Russia's approach to military reform, it is essential to keep Russia's national interests in mind. With the focus on the "near abroad," the effects of Russian military reform create unique opportunities for NATO in terms of pursuing more practical cooperation, and offer a real chance for deepened bilateral and multilateral military partnership, especially in Central Asia (although the special interests of all parties have to be considered). Undergoing what is probably the most important reform in the past 150 years, every aspect of Russia's military has been changed. The process of Russian military reform started slowly, but has now gained speed, and can point to some successes, despite the remaining challenges. As one observer noted, "In comparison with other military reforms introduced since the collapse of the Union of Soviet Socialist Republics (USSR), this one

\footnotetext{
54 NATO, "Final statement of the meeting of the North Atlantic Council at the level of Foreign Ministers," held at NATO Headquarters, Brussels, on 7 December 2011; available at http://www.nato.int/cps/en/natolive/official_texts_81943.htm?selectedLocale=en.

55 Nezavisimoe voennoe obozreni, "Urgent Problems and the Logic of Military Reform," 71.
} 
is for real." ${ }^{56}$ The extension of General Makarov as Chief of Defence underlines the will by Minister Serdyukov to proceed with the "New Look." Although Timothy Thomas predicted in 2010 that the "recasting of the Red Star is well underway," the current course of events appears to be different, not only because the structure and the conceptual guidelines have been changing, but also because the mentality within the Russian military is about to change drastically. ${ }^{57}$ In answering the question posed at the beginning of this concluding section, it is obvious that the Russian military reforms currently under way will not lead to the "Re-Rising of the Red Star," but rather to a new Russian military that in the near future will be able to ensure Russia's national interests, whether they are threatened from the outside or internally. But the new Russian armed forces will have more than just a "New Look," since these reforms will enhance Russia's options to cooperate and enhance regional security, whether working with or without partners. Concerning the possible threat posed by Russia's armed forces, the Estonian Defense Minster Mart Laar noted in September 2011 that "Russia poses much more danger through its internal weaknesses," and the current manifestations by the Russian opposition throughout the country underline this assessment. ${ }^{58}$

56 Herspring, "Is Military Reform in Russia for 'Real'?," 151.

57 Thomas, Recasting the Red Star, 363.

58 Agence France-Presse, "Russian Military Might Worries Region: Estonian General," DefenceTalk (26 September 2011); available at http://www.defencetalk.com/russian-militarymight-worries-region-estonian-general-37234 (15 November 2011). 


\section{Bibliography}

Arbatov, Alexei G.. "Military Reform in Russia: Dilemmas, Obstacles, and Prospects." International Security 22, no. 4 (1998): 83.

Baev, Pavel K.. "Military Reform Against Heavy Odds." In Russia After the Global Economic Crisis, 170-72. Washington: Peterson Institute for Internal Economics, 2010.

Baev, Pavel K.. Russian Military Perestroika. Vol. 45 . U.S. Europe Analysis 45 . Brookings Institution Center on the United States and Europe, 2010.

Beasly, Kris D.. Russian Military Reform from Perestroika to Putin: Implications for U.S. Policy. Maxwell AFB Alabama: Air University, 2004.

Blank, Steven. Russian Military Politics and Russia's 2010 Defense Doctrine. Carlisle, PA:: Strategic Studies Institute, U.S. Army War College, 2010.

Capezza, David. "Translating Russia’s Military Reform." Small Wars Journal (2009).

de Haas, Marcel. "Russia's Military Doctrine Development." In Russian Military Politics and Russia's 2010 Defense Doctrine. Carlisle, PA: Strategic Studies Institute, U.S. Army War College, 2010.

Felgenhauer, Pavel. "Rearmament Declared the Main Issue in Russian Military Reform." Eurasia Daily Monitor 7, no. 122 (2010).

France-Presse, Agence. Russian Military Might Worries Region: Estonian General. DefenceTalk, 2011.

Herspring, Dale R.. "Is Military Reform in Russia for 'Real'? Yes, but ...." In The Russian Military Today and Tomorrow: Essays in Memory of Mary Fitzgerald, 153. Carlisle, PA: Strategic Studies Institute, U.S. Army War College, 2010.

Kramnik, Ilya. Military Reform: Basic Guidelines. RIA Novosti, 2010.

Kramnik, Ilya. Russian Military Reform in Times of Crisis. RIA Novosti, 2010.

McDermott, Roger. "Russian Military 'New Look' Hovers in Limbo." Eurasia Daily Monitor 8, no. 206 (2011).

McDermott, Roger. "Serdyukov Signals 'First Stage' in 'Military Reform' Nearing Completion." Eurasia Daily Monitor 8, no. 191 (2011).

Medvedev's Missile Shield Remarks May Be Election Rhetoric - NATO Chief. RIA Novosti, 2011.

Medwedew lobt Beziehungen mit Indien als privilegierte Partnerschaft [Medvedev Praises Relationship with India as a Privileged Partnership]. RIA Novosti, 2011.

NATO. "Final statement of the meeting of the North Atlantic Council at the level of Foreign Ministers." Brussels: NATO Headquarters, 2011.

Russia Has Lost its Army. DefenceTalk, 2003.

Russia, Britain plan to improve military ties. RIA Novosti, 2011. 


\section{THE QUARTERLY JOURNAL}

Russian Military Has 'No one left to draft'. RIA Novosti, 2011.

Senior Russian Army Officers Resign over Military Reforms - Paper. RIA Novosti, 2011.

Thomas, Timothy L.. Recasting the Red Star: Russia Forges Tradition and Technology through Toughness . Fort Leavenworth, KS: Foreign Military Studies Office, 2011.

Three Key Factors at Play for Russian Modernization. DefenceTalk, 2011.

Urgent Problems and the Logic of Military Reform. Russian Politics and Law 48, no. 3 (2010): 59. 